\title{
Survey for Increase of Power Production Based on Quantitative Evaluation of Thermal Efficiency with Thermal Performance Analysis Simulator for a Reheating Cycle Boiling Water Reactor
}

$\begin{array}{cllll}\text { O学 } & \text { 中島 } & \text { 千秋(東北大院) } & \text { 学 坂本 } & \text { 桃子(東北大院) } \\ \text { 正 竹田 } & \text { 陽一(東北大) } & \text { 正 大地 } & \text { 昭生(東北大) }\end{array}$

Chiaki NAKAJIMA, Fracture and Reliability Research Institute, Tohoku University, Aoba6-6-01, Aramaki, Aoba-ku, Sendai, Miyagi Momoko SAKAMOTO, Fracture and Reliability Research Institute, Tohoku University Yoichi TAKEDA, Fracture and Reliability Research Institute, Tohoku University Akio OHJI, Fracture and Reliability Research Institute, Tohoku University

Key words: Nuclear Power Plant, Thermodynamic Analysis, Performance Analysis Simulator, Thermal Efficiency

\section{1. 緒言}

原子力発電は， $\mathrm{CO}_{2}$ 排出削減効果やエネルギー安定確保の面で 優れており，今後さらに重要な電源となることが予想される. 従 来日本の原子力プラントは定格電気出力一定運転を実施してい たが, 2001 年に熱出力を一定に保つ定格熱出力一定運転が認可さ れ, 冬季の海水温度低下による発電出力の上帠やプラント効率の 改善を直接電気出力上界に反映できる運転方法となった。 しかし， 現在では運転開始から 30 年以上経過したプラントも存在し，経 年化による機器性能の変化に伴い，設計運転状態からのずれ，さ らにはプラント効率の低下も考えられる。このような状況で効率 よく発電を行うためには, 各機器への適切な対処が望ましい. そ のため, プラント性能変化の要因特定や, 機器性能変化のプラン ト全体へ及ぼす影響度評価を目的とする性能解析手法の確立が 望まれている.

これまでの研究[1]において，基本的な原子力発電システムを対 象とした熱的性能解析シミュレータが開発され, 復水器と低圧タ ービン(Low Pressure Turbine; LPT)の性能変化に伴う発電端出力の 増加摔が定量的に明らかにされた。しかし，現在稼働中の原子力 プラントの中には，効率向上のため再熱サイクルを採用している ものが多数存在し，システムの複雑化からここれまでのシミュレ 一タでは対応することが困難である. そのため再熱サイクルにも 対応した解析手法を開発し，プラント評価一用いることが望まし い. そこで本研究では, 構成機器の熱力学的作動原理に基づき, 蒸気再熱式原子力プラントを対象とした熱的性能解析シミュレ 一夕を開発し, 運転条件の変動や機器性能の変化がプラント電気 出力や構成機器状態値に与える影響を定量的に評価する。

\section{2. 熱的性能解析シミュレータの構成条件}

\section{1 解析プログラムとシミュレー夕設計条件}

熱的性能解析シミュレータを作成するにあたり，本研究では基 盤として電力中央研究所が開発した発電システム熱効率解析汎 用プログラム(EgWin)を使用した。 このプログラムは，逐次計算 法と，線形計算法の長所を組み合わせた新たな計算手法を用いて おり，多様な発電システムを容易に解析・評価することが可能で ある. 本研究では再熱サイクルを用いた既存の 840MW 級原子力 発電プラントを対象としてシステムを構成し，解析を穾施する.

システム構成の概要を Fig. 1 に示す。設計時のプラント状態を 再現寸るため, 設計計画時条件に基づく解析を䒠施した。本研究 では帮際の運転を想定し，原子炉からは一定の圧力・温度・湿り 度の蒸気が発生すると仮定した。

\subsection{1 湿分分離加熱器およひ湿分分離翼}

再熱式プラントでは，高圧タービン(High Pressure Turbine;HPT) 出口後に湿分分離加熱器を設置しており, 湿分分離器での汽水分 離と, HPT 抽気および主蒸気を加熱源とする二段再熱が行われる. 火力プラントと比較すると, 原子力プラントは主蒸気が湿り蒸気 であるという点で異なり，タービンは湿り域にて運転される特徽 がある. しかし再熱式プラントでは, 高圧タービン出口後の圧力 低下した蒸気が, 高温・高圧の蒸気で熱されることにより乾き 蒸気となり, 低圧タービン入口でのエンタルピが上昇する結果, 低圧タービンでの発電出力が増大する。

低圧タービン入口の蒸気温度は湿分分離加熱器への加熱蒸気 量を調整することによって制御されるが，50～100\%負荷時にお

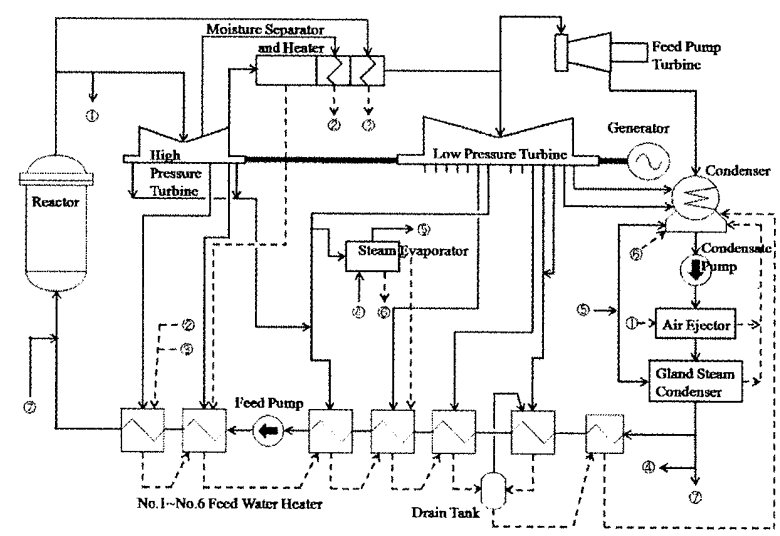

Fig. 1 A schematic diagram of reheating cycle BWR

いては可能な限り温度上昇させるため加熱蒸気弁を全開運用し ており，LPT 入口温度はほぼ一定である. したがって，HPT抽 気流量はHPT 入口流量によって算出し，主蒸気は湿分分離加熱 器出口温度が高温となる十分な流量を採択した。

また，原子力プラントではタービンは大部分が湿り域で運転さ れるため, タービン内の蒸気のエンタルピは圧力と温度に加えて 湿り度によって決定する. 蒸気中の水滴速度は蒸気速度の約 10 分の 1 であるため, 水滴はタービンの羽根入口背面に衝突し, ブ レーキ作用を引き起こす。したがって湿り度の增大によりタービ ン効率が低下する. その対策として，LPT 動翼には羽根入口背面 部に湿分分離溝が設置され，付着した水分をドレンとして除去し ている. タービン断熱効率は蒸気の出入口压力・温度・エンタル ピから算出できるが, ドレン除去により蒸気の湿り度が低下する ため, 断熱効率は各段ごとに決定される. また, 原子力プラント は火力プラントに比へ熱落差が小さく，LPT 最終段での排気損失 がタービン出力に大きく影響を与える.

2.1.2 タービン䮎動原子炬給水ポンプ

本研究で対象とした発電プラントの原子炬給水ポンプはター ビン駆動である.このポンプは給水ポンプ駆動用タービンの回転 を直接ポンプ軘動力として利用するため，流量による回転数制御 が可能かつエネルギ一変換ロスの減少により, 常に高効率で駆動 できる. 給水ポンプ性能は Q-H 曲線(叶出し量 $Q\left[\mathrm{~m}^{3} / \mathrm{min}\right]$, 全揚 程 $H[\mathrm{~m}]$ )で表わされ, 効率は設計傎より設定した. シミュレータ 上で再現するにあたり，駆件タービンとポンプの出力・軸動力を 一致させる必要がある. よって流量, 揚程よりポンプ軸動力を外 部で計算し, タービンで必要な流量を算出し入力した。

\subsection{3 構成機器における熱収支の決定}

$100 \% \cdot 75 \% \cdot 50 \% \cdot 25 \%$ 部分負荷時設計ヒートバランスを基 に設計時のプラント状態を再現するシミュレータを構築した. 原 子力プラントでは主蒸気の状態值が一定であるため, 負荷変動は 主蒸気流皇の変動により調節している.したがってシミュレータ の作成に際し, 主蒸気流量を基淮にヒートバランスの解析行った. 給水加熱器の性能は, 末端温度差(TD)及び初期温度差(DC)で表 される. 原子炬給水系の状態を正確に再現するため, 給水の出入

[No. 2009-2］日本機械学会 東北支部第45期秋季講演会 講演論文集（2009.9.26） 
口温度と DC を固定し，タービン抽気流量は熱収支から算出する ものとした.

プラント熱効率は以下の式より算出した.

$Q_{s}=G_{S}\left(H_{1}-H_{2}\right)$

$\eta_{\text {gross }}=P / Q_{S} \times 100$

$Q_{S}$ : 原子炉熱出力 $[\mathrm{kJ} / \mathrm{s}] \quad G_{S}$ : 原子炉発生蒸気量 $[\mathrm{kg} / \mathrm{s}]$ $P$ : 発電端出力 $[\mathrm{kW}] \quad H_{I}$ : 原子炉出口エンタルピ $[\mathrm{kJ} / \mathrm{kg}]$ $\mathrm{H}_{2}$ : 原子炉入口エンタルピ $[\mathrm{kJ} / \mathrm{kg}] \quad \eta_{\mathrm{gras}}$ :グロス熱效猝 [\%]

\section{3. 熱的性能解析}

3.1 シミュレー夕の妥当性検証

作成したシミュレータの妥当性を検証するため, 主蒸気流量を 変動させ, 発電端出力・熱効率の解析を行った. その際, タービ ン率熱効率・給水加熱器・再熱器の性能は主蒸気流量に対空して 変動するものとした. Table 1に結果を示す. 出力は設計值とほぼ 同值で, 熱効率も最大で誤差的 $0.41 \%$ と精度良く解析できている. したがつて本シミュレータの妥当性法示されたと考えられる。

3.2 プラント運䡛状態の把握

本シミュレータを用いてプラント運用を最適化するためには, 現状の運転状態の正確な把握が不可欠である. そこで，一年間の プラント運転の実測值を基に，シミュレータによる熱効率解析を 行った. 各機器性能を決定づける主蒸気流量を求めるデータとし て, HPT 入口流量・総主蒸気流量・総給水流量の 3 項目をそれぞ れ採用した場合に対し，解析を行った結果を Fig. 2 に示寸.

発電出力結果より総給水流量及び総主蒸気流量を基準とした 計算結果が実測值に最も近い值を示した. また，実測値の出力変 動においては HPT 入口流量・総主蒸気流量を基にした計算デー タが同様の傾向を示した，その原因としては，主蒸気がタービン 出力八直接影響を与えること，また，定格熱出力一定運転のため に給水流量の変動が原子炬で抑えられることがあげられる. した がつて，正確な運車云状態把握のためには総主蒸気流量を用いるこ とが望ましいと考えられる。

\section{3 熱効㸉改善による出力増加の検討}

定格熱出力一定運転を実施する原子力プラントでは，熱効率の 改善により出力増加が可能である. 本研究では熱効率改善策とし て再熱サイクル採用とタービン最終段長翼化について解析を行 った. その際，実際のプラント運転て熱効率変動に最も影響を与. 方る復水器真空度を変化させ，原子炬定格熱出力条件下で熱效率 を解析し比較するものとした。

まず，本研究で対象とした原子力プラントが再熱サイクルの適 用により得られた熱効率の向上度を, 再熱サイクルと非再熱サイ クルの比較解析により評価した. 非再熱サイクルのシミュレータ は, 本シミュレータの湿分分離加熱器を湿分分離器に置換したも のとし，主蒝気条件と流量を一致させることにより比較を行った。 なお，低圧タービン断熱効率はこれまでの研究で作成された非再 熱式原子力プラントを参考に決定した. 解析結果を Fig. 3 に示守. 再熱・非再熱共に, 復水器真空度の増加に伴いタービン有効熱落 差が増大し，熱効率は増加したが，排気損失も増加するため $719 \mathrm{mmHg}$ 付近を境に減少に転じた。 また，再熱サイクルを用い たことで，平均 $3.87 \%$ の熱効率向上度が得られたことが分かる.

更に，低左タービン最終段長翼化を検討する，長翼化により環 状面積を増加させ，流出速度を減少させることで排気損失を低減 し敓效率の向上を図ることができる. 本研究において刘象とした プラントの最終段翼長は 41 in(環状面積的 $11.5\left[\mathrm{~m}^{2} / \mathrm{FLOW]}\right.$ )である が，プラント設備容量を考虑した上で A 翼(13.3 [ $\left.\mathrm{m}^{2} / \mathrm{FLOW]}\right), \mathrm{B}$ 翼(173 [ $\mathrm{m}^{2} /$ FLOW] について排気損失曲線を決定し，解析を行つ た. 解析結果を Fig. 4 に示寺. 復水器真空度 $722 \mathrm{mmHg}$ の基淮時 にお忛万熱効率向上率は，A翼で $126 \%$ (約 $10.6 \mathrm{MW}$ ), B翼で $2.84 \%$ (約 29.1MW)が見込まれる. A 翼の場合，熱効率の最大值は現行 タービンと同様に $718 \mathrm{mmHg}$ 前後であるため, タービンのタの改 良で, 最適運転点が得られる。一方 B 翼を用いた場合, 解析範井 では復水器真空度の増加に伴い熱効率が上昇し続けるため, 復水 器性能の改善により効果的に出力増加を得ることが可能である.

\section{4. 結言}

本研究では，蒸気再熱式原子力プラントをモデルとした主蒸気 流量を基淮とする熱的性能解析シミュレ一夕を作成し，負荷変動 に対して精度良くプラント状態值を再現することができた。 それ を基に，実際のプラント運転実測值に基づく解析を行い定常運転 状熊の把握と，プラント熱効率改善による出力増加の検討を行っ たその結果，再熱サイクル敵用により平均 $3.87 \%$ の熱効率向上
Table 1 Summary of analysis results under the part load conditions

\begin{tabular}{|c|c|c|c|c|}
\hline & \multicolumn{2}{|c|}{ Analysis result } & \multicolumn{2}{c|}{ Design value } \\
\hline Main steam flow[th] & Efficiency[\%] & Output[MW] & Efficiency]\%] & Output[MW] \\
\hline 2348.07 & 32.37 & 419.88 & 32.31 & 418.50 \\
\hline 3507.12 & 33.86 & 629.66 & 33.78 & 627.75 \\
\hline 4735.16 & 34.55 & 839.76 & 34.41 & 837.00 \\
\hline
\end{tabular}

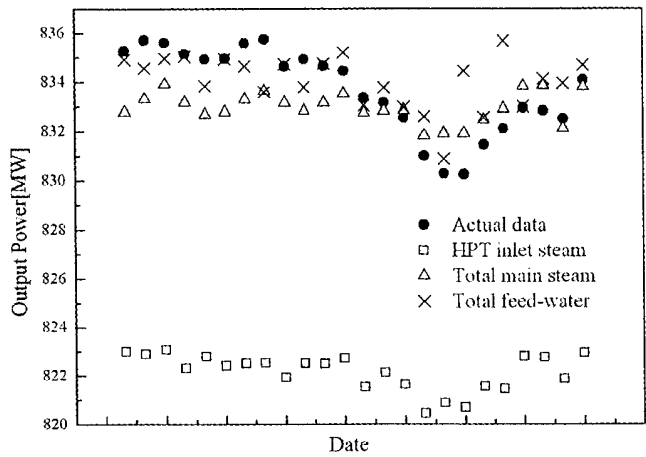

Fig. 2 Comparison of power outputs estimated by a simulation vs actual output under operation.

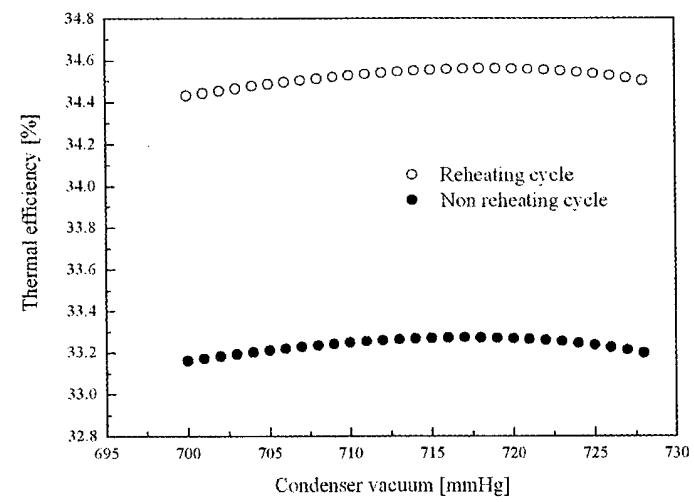

Fig. 3 Thermal efficiencies of reheating cycles vs non reheating cycles.

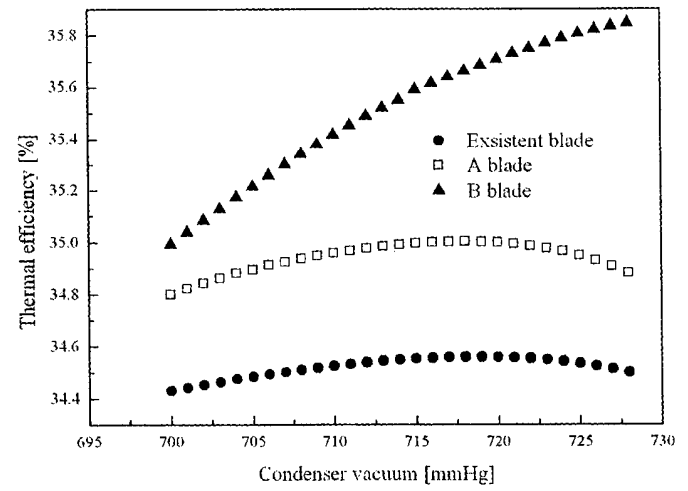

Fig. 4Thermal efficiency depending on last stage blade length based on condenser vacuum.

度を得たことが明らかれなった．また，タービン最終段長翼化を 想定した解析の結果, $722 \mathrm{mmHg}$ 時で $\mathrm{A}$ 翼 $1.26 \%$, B 翼 $2.84 \%$ の 熱効率向上度が得られる他，最適運転のためには復水器性能の改 善が重要であることが明らかになった。

本研究で開発した熱的性能解析シミュレー夕は汎用性が高く, プラント運用の手段として適当なものである. 今後，害際の運用 に即した，実測值を基に運転状態を把握する解析手法の更なる碓 立を図る必要がある.

参考文献：

[1]䛀本ら，原子力プラントの熱的性能解析シミュレータの開発とプラント 運用評価, 日本機械学会東北学生会, 第 38 回卒業研究発表㗕演会講演論文 集, (2006), pp.15-16

[2] F. G Baily, K. C. Cottor, and R. C. Spencer, Predicting the Performance of L arge Steam Turbine-generators Operating with Saturated and Low Superheat Steam Conditions, American Power Conferenoe, April 25-27,(1967) 